\title{
Peat morphology and geochemistry of Šijec bog (Slovenia)
}

\author{
VAlentina PezdiR*, Teja ČERU, Mateja Gosar
}

Geological Survey of Slovenia, Dimičeva 14, SI-1000

Ljubljana, Slovenia (*correspondence:

valentina.pezdir@geo-zs.si)

\begin{abstract}
Ombrotrophic peatlands are good archive of historical atmospheric deposition as their only source of water is precipitation [1]. In Slovenia, peatlands represent a smaller area. In three areas (Pokljuka, Pohorje and Jelovica) are peatlands labelled as raised bogs. Our research is focused on Šijec bog on Pokljuka plateau that is among southernmost ombrotrophic peatlands in Europe [2] and covers an area of approximately $0.15 \mathrm{~km}^{2}$. In this work we present preliminary geochemical results and determine morphology of the peat bog that will be used for further detailed geochemical research of Šijec bog which is foreseen in this summer..

Šijec bog morphology was determined in February 2020 using the ProEx (MALA Geoscience, Sweden) ground penetrating radar with an RTA (Rought Terrain Antennas) unshielded $50 \mathrm{MHz}$ bistatic antenna. GPR results indicate four deeper peat depressions, measuring up to $9 \mathrm{~m}$ in depth. Based on the morphology of the bog, cores for further geochemical analysis will be determined. Under peat, the GPR signal was lost due to presence of clayey lake sediments.

First geochemical study on Šijec bog was already conducted in 1999, when 5 composite samples of different sections $(0-10 \mathrm{~cm}, 10-20 \mathrm{~cm}, 20-30 \mathrm{~cm}, 30-50 \mathrm{~cm}$ and $50-$ $70 \mathrm{~cm}$ ) were taken. Samples were analysed in Bureau Veritas Mineral Laboratories at Vancouver, Canada. The air dried samples were ground to analytical grain size $(<0.063 \mathrm{~mm})$ and were analysed following the aqua regia $(1: 1: 1 \mathrm{HCl}$ : $\mathrm{HNO}_{3}: \mathrm{H}_{2} \mathrm{O}$ ) extraction. Concentrations of following 36 elements were determined: $\mathrm{Ag}, \mathrm{Al}, \mathrm{As}, \mathrm{Au}, \mathrm{B}, \mathrm{Ba}, \mathrm{Bi}, \mathrm{Ca}, \mathrm{Cd}$, $\mathrm{Co}, \mathrm{Cr}, \mathrm{Cu}, \mathrm{Fe}, \mathrm{Ga}, \mathrm{Hg}, \mathrm{K}, \mathrm{La}, \mathrm{Mg}, \mathrm{Mn}, \mathrm{Mo}, \mathrm{Na}, \mathrm{Ni}, \mathrm{Pb}, \mathrm{S}$, $\mathrm{Sb}, \mathrm{Se}, \mathrm{Sr}, \mathrm{Te}, \mathrm{Th}, \mathrm{Ti}, \mathrm{Tl}, \mathrm{U}, \mathrm{V}, \mathrm{W}, \mathrm{Zn}$. Most elements have elevated element concentrations in upper $20 \mathrm{~cm}$ of peat. In the peat section $10-20 \mathrm{~cm} \mathrm{~Pb}(125.1 \mathrm{mg} / \mathrm{kg}), \mathrm{Cd}(1.46 \mathrm{mg} / \mathrm{kg})$ and $\mathrm{Hg}(171 \mu \mathrm{g} / \mathrm{kg})$ stand out with higher concentration values. Higher element concentration values in upper section are most likely the result of anthropogenic activities in the Pokljuka plateau wider surroundings. Dust particles originating from these activities were deposited on peat by short and long-range wind transport and precipitation.
\end{abstract}

[1] Charman (2002) Peatlands and Environmental Change, 312 p. [2] Kutnar (2000) Phyton (Austria) 40/4, 123-128. 